\title{
Assia Djebar: uma busca identitária alicerçada no entrelugar literário
}

\author{
franco-árabe/ Assia Djebar: a search for identity grounded in-between
}

\author{
Franco-Arab literature
}

\author{
Maria Rennally Soares da Silva* \\ Francisca Zuleide Duarte de Souza **
}

\begin{abstract}
RESUMO
No âmbito da literatura pós-colonial, o povo argelino buscou na escrita literária, uma forma resistir às formas de subordinação às quais foram submetidos, no contexto de agenciamento das marcas e rupturas causadas pelo regime colonialista. Alguns escritores argelinos passaram a escrever textos literários em língua francesa com o intuito de serem ouvidos para além-fronteiras. A escritora argelina Fatima Zohra Imalayène, conhecida pelo pseudônimo Assia Djebar, obteve grande destaque por denunciar, em suas obras, a situação de subalternização vivenciada pelas mulheres argelinas, bem como o massacre pelo qual passou o povo argelino, submetido às imposições dos colonizadores franceses. Essa pesquisa bibliográfica (GIL, 2008) tem como objetivo discutir elementos que ratificam o entrelugar literário na obra da referida escritora argelina. Para tanto, temos como base teórica os estudos de Bhabha (2005) a respeito do entrelugar e do hibridismo cultural, bem como as reflexões de Deleuze e Guatari (2000) sobre a perspectiva do devir revolucionário. Inserida no contexto diaspórico, a autora vivenciou o regime colonialista instalado em seu país de origem e buscou, na literatura, uma forma de superação das rupturas deixadas pelo colonialismo e pelas imposições patriarcalistas presentes em sua identidade cultural. Encontramos, em suas obras, uma espécie de desconforto com relação à sua identidade. Por não se enxergar totalmente argelina e nem totalmente francesa, ela expressa em suas obras uma angústia que a leva a escrever para "dizer-se" (DJEBAR, 1985, p. 91) e para dar voz ao seu povo, especialmente às mulheres árabes, que permanecem na invisibilidade. Esta voz é dada através da escrita literária em língua francesa. Assim, o entrelugar literário franco-árabe de Assia Djebar lhe causa o sentimento dúbio de liberdade e de afasia. Essa cisão identitária manifestou-se em toda a sua obra e a levou a viver entre os universos francês e árabe.

PALAVRAS-CHAVE: Assia Djebar; entrelugar literário; escritora argelina; construção identitária.
\end{abstract}

\begin{abstract}
In postcolonial literature, the Algerian people sought in literary writing a way to resist the forms of subordination to which they were subjected, through the agency of the scars and ruptures caused by the colonialist regime. Some Algerian writers began to write literary texts in French in order to be heard across borders. Fatima Zohra Imalayène was one of them. Best known by the pseudonym Assia Djebar, the Algerian writer became widely known by denouncing the situation of subalternation experienced by Algerian women in her works, as well as the massacre that Algerian people experienced under the impositions of French colonizers. This bibliographic research (GIL, 2008) intends to discuss elements that ratify the literary in-between in the work of Assia Djebar. To do so, we used Bhabha's (2005) concepts in-between and cultural hybridism, as well as the reflections of Deleuze and Guattari (2000) on the perspective of the becoming-revolutionary as our theoretical framework. In the context of diaspora, the author experienced the colonialist regime installed in her native country and sought, in literature, a way of overcoming the ruptures left by colonialism and the patriarchal impositions present in her cultural identity. We can find a type of discomfort regarding her identity in her writings. Because she sees herself as being neither totally Algerian nor totally French, she expresses in her works an anguish that leads her

\footnotetext{
* Doutoranda pelo Programa de Pós-Graduação em Literatura e Interculturalidade - Universidade Estadual da Paraíba. Campina Grande - PB, Brasil. Endereço eletrônico: rennally.f@ hotmail.com.

** Doutora em Letras pela Universidade Federal da Paraíba. Docente da Universidade Estadual da Paraíba, membro efetivo do Colegiado do Programa de Pós-Graduação em Literatura e Interculturalidade. Campina Grande- PB, Brasil. Endereço eletrônico: zuleide.duarte@ hotmail.com.
} 


\section{Revista Leteas Racar}

ISSN: 2317-2347 - v. 7, Edição Especial (2018).

to write "to tell herself" (DJEBAR, 1985, p. 91) and to give voice to her people, especially to Arab women, who remain invisible. This voice is given through her literary writing in French. Thus, Assia Djebar's Franco-Arab in-between literature causes her an ambivalent feeling of freedom and aphasia. This identity breakup manifested itself throughout her work and led her to live among the French and Arab worlds.

KEYWORDS: Assia Djebar; Literary in-between; Algerian writer; identity construction.

\section{Introdução}

Desde a Antiguidade, a arte literária é considerada uma experiência de expressão e de reconstrução da realidade social. Os estudos da sociologia da literatura, introduzidos por Georg Lukács (1963) a partir da obra A teoria do romance asseveram que a obra literária constitui uma forma de representação e também de ampliação da realidade social. Muito antes, Madame de Staël (1980, apud ALMEIDA, 2010) já buscava relacionar a literatura e os eventos sociais propondo três parâmetros de análise para o texto literário, sendo eles: 1) uma leitura diacrônica do texto literário, considerando que ele se transforma na medida em que ocorrem mudanças nas sociedades; 2) uma leitura espacial, considerando o espaço nacional no qual o texto literário está inserido e 3) a observação da contradição entre a literatura necessária e aquela que é publicada, de fato (NETO, 2007).

Assim, é possível afirmar que a literatura se constitui em um lugar onde podem ser discutidos diversos aspectos importantes para a sociedade contemporânea pósmoderna, na qual o ser humano percebe-se diante de uma realidade multifacetada, cujas certezas outrora consideradas como verdades absolutas estão sendo o tempo todo repensadas e reformuladas (ALMEIDA, 2010).

$\mathrm{Na}$ contemporaneidade, as literaturas pós-coloniais consistem em formas de superação da dominação e da subordinação pela qual os povos culturalmente híbridos passaram (PEREIRA; SOUZA, 2016), narrando histórias diferentes das que são contadas pelo domínio imperialista, em busca de resistir, preservar e resguardar os valores culturais de origem, sem perder o espaço conquistado no território da antiga metrópole, para dizer-se e reconstruir-se.

É comum encontrarmos nas literaturas pós-coloniais de língua francesa, narrativas cujas personagens trazem características culturais de duplicidade e de ambiguidade, revelando o hibridismo identitário de que fala Homi Bhabha (2005) em seus estudos. Assim, as "zonas de contato" (ALMEIDA; SOUZA, 2016, p. 284) 


\section{Revista Leteas Racar}

ISSN: 2317-2347 - v. 7, Edição Especial (2018).

expressas nas literaturas pós-coloniais entre o sujeito diaspórico e o novo ambiente cultural no qual está inserido, se tornam um meio de superar a subalternização a qual o sujeito foi condicionado.

As mudanças e a reconstrução identitária do indivíduo pós-colonial inserido em realidades diaspóricas, seja como exilados, imigrantes, refugiados, que partem de seu país de origem seja em razão da globalização, seja para buscar em outros países uma formação acadêmica ou técnica, seja em razão da organização econômica do seu país de origem (PEREIRA; SOUZA, 2016), são temas que precisam ser investigados tendo em vista a sua emergência nas literaturas mencionadas.

No contexto da colonização de países africanos, temos a Argélia, cujo povo foi massacrado e explorado pela França. Esse povo, que havia sido derrotado pelo seu colonizador, encontrou, na expressão literária, uma forma de não silenciar diante da subordinação à qual foi submetido, a partir de escritores magrebinos que escreviam textos em língua francesa - que representava a língua de ligação com o restante do mundo (COMBE, 2010). Tal fato configurou-se em um grito de socorro e em uma exposição de denúncias e de revoltas no período da conflituosa colonização desse povo.

Neste âmbito literário magrebino, temos estudado a obra da escritora argelina Fatima Zohra Imalayène (1936-2015) que, tendo adotado o pseudônimo de Assia Djebar, tornou-se autora de uma vasta produção que compreende desde romances, novelas, poemas, ensaios até peças de teatro e obras cinematográficas, adotando como tema central de suas produções a emancipação feminina e a situação conflituosa da Argélia à época da colonização. Essa escritora viveu até os 17 anos em sua terra natal e, depois disso, esteve exilada em Paris, morando posteriormente nos Estados Unidos e permanecendo em trânsito entre a Argélia, a França e os Estados Unidos até 2015.

Situada no âmbito dos estudos bibliográficos (GIL, 2008), esta pesquisa tem como objetivo discutir elementos que ratificam o entrelugar literário na obra da referida escritora argelina, ou seja, uma mulher que, inserida no contexto diaspórico, tendo passado pelo regime colonialista instalado em seu país de origem, buscou na literatura uma forma de superação das marcas deixadas pelo colonialismo e pelas imposições patriarcalistas e machistas presentes em sua identidade cultural.

Assia Djebar demonstra estar neste entrelugar, quando por um lado, a sua escrita sempre evoca situações vivenciadas na Argélia, em seu seio familiar, sejam elas 


\section{Reuista Leteas Racas}

ISSN: 2317-2347 - v. 7, Edição Especial (2018).

lembranças tenras ou dolorosas. Por outro lado, ela se encontra imersa na língua e na cultura francesa, trazidas pelo colonizador desde a sua infância. Assim, essa escritora manifesta, em suas obras, uma espécie de desconforto com relação à sua identidade. Por não se enxergar totalmente argelina e nem totalmente francesa, a autora demonstra uma angústia que a leva a escrever para “dizer-se” (DJEBAR, 1985, p. 91) e para encontrar respostas aos seus questionamentos.

Sobre essa autora, destacamos que a maior parte dos seus romances emergem de projetos autobiográficos (SOARES, 1990) e que é tida como uma das mais influentes personalidades da literatura feminina do Magrebe, considerada em algumas academias como a porta-voz da mulher árabe através da literatura. Exilada na França durante alguns anos e, posteriormente, em errância entre a França e a Argélia, através da escrita literária, narra a si mesma e à sua nação de forma dicotômica. Ao tempo em que não consegue expressar as suas mais afetivas lembranças em língua francesa, pois esta é a língua do colonizador, Djebar se utiliza desta língua para contar a sua história e a do seu país, removendo tanto a mulher árabe, quando a Argélia, do lugar de silenciamento ao qual ambas foram condicionadas (SILVA, 2017).

A percepção da problemática de uma dicotomia identitária franco-árabe na produção literária de Assia Djebar nos levou a situá-la enquanto uma escritora que permanece neste entrelugar por causa das rupturas causadas pelo processo de colonização, que fragmentaram a identidade cultural da referida escritora. Neste artigo, portanto, temos como fundamentos teóricos os estudos de Bhabha (2005) a respeito do entrelugar e do hibridismo cultural, bem como as reflexões de Deleuze e Guatari (2000) sobre a perspectiva do devir revolucionário. Também situamos a escritora argelina Assia Djebar, apontando-a como alguém que permanece no entrelugar literário francoárabe, utilizando-se da língua francesa para narrar a si mesma e à sua nação.

\section{A literatura como lugar de reconstrução identitária no contexto magrebino}

Uma das discussões mais importantes do âmbito dos estudos culturais versa sobre a questão da constituição de identidades culturais, cujas reflexões de Homi Bhabha (2005) acerca desse tema são comumente visitadas. Esse estudioso problematiza a compreensão das identidades culturais compostas de forma singular, a 


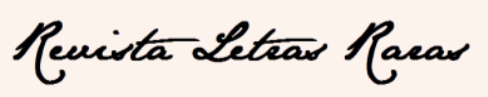

ISSN: 2317-2347 - v. 7, Edição Especial (2018).

partir de categorias pré-definidas, a exemplo das categorias de classe e de gênero. Ele afirma que as identidades se constituem nas fronteiras de diferentes realidades. $\mathrm{O}$ sujeito que se encontra nesses interstícios sociais e subjetivos está situado em um entrelugar.

Os interstícios que se formam nas fronteiras criam compartimentos múltiplos na constituição da identidade cultural do sujeito; esse espaço compartimentado pode ser chamado de entrelugar; é nele que os grupos subalternizados têm a possibilidade de transitar de uma fronteira a outra adquirindo empoderamento e hibridizando a sua subjetividade (BHABHA, 2005), assim como ocorre com os povos que foram colonizados. Uma vez que tiveram contato com a cultura do colonizador, os espaços culturais se cruzaram; embora esse se caracterize um contato de imposição; um ir ao outro num movimento de flechas, saindo de um ponto para conquistar o outro (GLISSANT, 1995).

O entrelugar possibilita a ultrapassagem do enraizamento da árvore - analogia tecida por Deleuze e Guatari (2000) e abre espaço à ideia de rizoma, do entrecruzamento das diferenças culturais pensado por Glissant (1995) através da noção de crioulização, dos horizontes que se cruzam; da substituição da unicidade pela multiplicidade e da exclusão pela relação. É nessa perspectiva que enxergamos a produção literária dos povos magrebinos, cuja história perpassa pela colonização, bem como pela superação desse capítulo de sua história. Essa ultrapassagem e esse recomeço não se dá através de um retorno às origens culturais de tais povos; mas, sim, a partir de identidades híbridas, crioulizadas, de horizontes diversos que se cruzam.

Durante décadas o continente africano sofreu com brutais invasões, ocupações e com a instauração do sistema colonial em vários países. A partir de então, a África passou a estar sob a dominação dos poderios britânico, espanhol, português e francês e subdividida em colônias submetidas ao domínio imperialista (UZOIGWE, 2010). Nesse contexto, a região do Magrebe, situada ao Norte do deserto do Saara, tornou-se o terreno de caça de diversos países, inclusive do império francês que, de modo cruel e violento, colonizou os povos dessa região, impondo a língua francesa como idioma oficial do local. A língua do colonizador tornou-se o símbolo da despersonalização cultural do povo magrebino (SOARES, 1990).

Na Argélia, entre 1954 e 1962, diversas organizações nacionalistas se integraram à FLN (Frente de Libertação Nacional) e, através deste movimento revolucionário que 


\section{Revista Leteas Racar}

ISSN: 2317-2347 - v. 7, Edição Especial (2018).

liderou a Guerra pela Independência Argelina, este país se viu livre do jugo do poderio europeu (BOAHEN, 2010). Contudo, apesar da independência alcançada, os impactos causados pelo colonialismo europeu ocasionaram brutais rupturas identitárias na cultura argelina, sendo a principal delas, o impulso diaspórico, que conduziu o povo argelino ao exílio e à migração para as antigas metrópoles em busca de superar a exclusão social, de alcançar estabilidade econômica por meio de uma melhor formação profissional ou de superar as amarras ideológicas e/ou religiosas da cultura de origem (PEREIRA; SOUZA, 2016).

A partir dos anos 1930 e 1940, quando a África passou a ser reconhecida pelos estudiosos enquanto um ambiente cultural, dividido em diferentes nações e possuidora de valores sociais e morais - tendo superado os discursos equivocados do século XIX difundidos pelo cientificismo, pelo evolucionismo, pelo darwinismo social, pelo materialismo histórico, pelas teorias raciais e pelas reflexões excludentes e discriminatórias de Hegel e de Pittard (1953) -, começaram a surgir estudos e reflexões acerca dos efeitos da diáspora sobre as culturas dos povos africanos (ALMEIDA, 2010), enxergando-a como um movimento de ruptura e de recriação de suas identidades culturais a partir das necessidades impostas a esses povos no cotidiano de um novo ambiente cultural.

De acordo os estudos de Mintz e Prince (2003), o principal efeito da diáspora seria a fragmentação das identidades desses povos dispersos, bem como a absorção de novos modelos e valores culturais. Logo, a reconstrução identitária e a elaboração de estratégias de organização de grupos de uma determinada cultura que se dispersaram, permanece alicerçada entre dois mundos: o universo cultural da terra de origem e o novo universo cultural encontrado na terra de chegada (ALMEIDA, 2010).

Desse modo, a permanência da cultura africana na identidade cultural do indivíduo no contexto da diáspora não implica na transposição completa de suas práticas culturais, mas sim, que a África está presente na maneira de organizar e de expressar a vida social (MINTZ; PRINCE, 2003). Segundo esses estudiosos, enxergar a formação de uma nova cultura de povos africanos em um lugar diferente do seu continente de origem não significa defender a sua europeização ou em achar, inocentemente, que eles deixaram para trás toda a sua bagagem cultural, mas, sim, que eles precisaram reconstruir valores sociais e culturais no novo território habitado. 


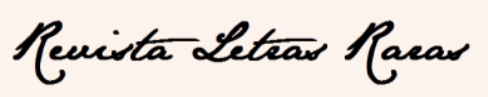

ISSN: 2317-2347 - v. 7, Edição Especial (2018).

Os povos inseridos no contexto da diáspora tiveram de reconstruir sua identidade cultural - que abarca a cultura, a tradição e a língua (BONNICI, 2012, apud PEREIRA; SOUZA, 2016) -, diante do novo mundo no qual se encontravam e mediante a demanda da formação de uma nova cultura que não seria totalmente assimilada à cultura europeia e tampouco estaria distante da cultura africana (MINTZ; PRICE, 2003).

Além disso, esse tipo de hibridez cultural (BHABHA, 2005) provoca no indivíduo que se encontra exilado a sensação da falta de lar, estando ele fora da sua terra de origem ou até mesmo já estando reconciliado com ela. Para o escritor uruguaio Mario Benedetti (1999, apud RAMALHO, 2013), o exílio deixa marcas que nunca se apagam completamente. Mesmo que o indivíduo retorne ao seu lugar de origem, a realidade a ser vivenciada nunca será a mesma, pois ele viverá a experiência do desexílio. Quando retorna ao país natal, o indivíduo deseja restabelecer não apenas a sua própria identidade, mas também a do seu país: espaço físico e conjunto de valores. A essa busca de reparação identitária pessoal e coletiva, Benedetti (1999, apud RAMALHO, 2013) chama de desexílio.

Em se tratando de escritores africanos exilados, as suas obras são diretamente influenciadas pela sua condição refugiada, uma vez que eles permanecem inquietos diante da nova identidade cultural que tiveram de construir. Nessa perspectiva, Ashcroft (et al., 1991) chama de literatura pós-colonial, toda obra nascida das mãos de povos que passaram pela experiência de colonização, sob o domínio de potências europeias entre o século XV e XX, demarcando as tensões estabelecidas entre esses povos e o monopólio imperialista. Assim, o povo argelino encontrou, na prática da escrita literária póscolonial, um caminho para reconstruir a sua identidade cultural após a brutal imposição das culturas dominantes (COMBE, 2010).

Diante do impasse linguístico entre o texto literário magrebino e a língua que o veicula, encontramos uma literatura que surgiu antes da independência de alguns países dessa região e que teve como principal temática o problema da aculturação e a denúncia de abusos cometidos pelo regime colonialista. A obra Portrait du colonisé, précédé $d u$ portrait du colonisateur (1957) do tunisiano Albert Memmi retrata todo o sofrimento de perda de identidade pelo qual passou o povo magrebino. Também a partir da leitura de Anthologie des Écrivains Maghrebins d'Expression Française, coletânea organizada 


\section{Reuista Letear Racar}

ISSN: 2317-2347 - v. 7, Edição Especial (2018).

por Memmi (1964), é possível encontrar os principais temas da literatura da literatura da época.

Encontramos o predomínio da descrição dos ritos da vida cotidiana magrebina em Mohammed Dib, Mouloud Feraoun, Ahmed Sefrioui, Mouloud Mammeri, dentre outros. Abordando a questão da aculturação, temos o mencionado Albert Memmi, Driss Chraibi e Yacine Kateb. Em um terceiro momento da literatura magrebina de língua francesa, a abordagem de temáticas centradas na Guerra da Argélia, nos impasses entre a colonização e o processo de descolonização, bem como a respeito da discriminação da mulher nas sociedades magrebinas podem ser encontradas em obras de Mourad Bourbonne, Assia Djebar, Malek Haddad, Mouloud Mammeri, Mohammed Dib, Marguérite Taos Amrouche e, posteriormente, Yamina Mechakra, Leïla Sebbar, Leila Aouchal, Hawa Djebali e Nadia Ghalem, Salima Ghezali, Hélé Béji, Maïssa Bey, Fatima Mernissi, Samira Negrouche, Hélène Cixous dentre outros.

Temos como exemplos de obras literárias magrebinas de língua francesa que apontam e discutem questões referentes à busca identitária do povo dessa região, a trilogia de Mohammed Dib, composta pelas obras: La grande Maison, L'Incendie e Le Métier à tisser, nas quais o personagem Omar apresentar ao leitor a vida na cidade de Tlemcen, onde em meio à guerra, prevalece a fome a miséria e, diante disso, os camponeses tomam consciência da situação de ruptura cultural na qual estão inseridos e começam a exercer um espírito de solidariedade, lutando para se ajudarem mutuamente.

Também pode-se citar o romance Nedjma, de Yacine Kateb, no qual a história da personagem principal está atrelada à da Argélia e, procurando a essência de Nedjma, a personagem encontra a sua pátria ocupada por estrangeiros. Na obra La rue des tambourins, a escritora Marguérite Amrouche narra a sua vida e o seu problema de ser cristã em meio a uma sociedade muçulmana. Também destacamos a obra L'amour, la Fantasia, de Assia Djebar, na qual a escritora dá voz às mulheres argelinas que foram durante muito tempo silenciadas e duplamente colonizadas (SILVA, 2017) ${ }^{1}$. Assim,

\footnotetext{
${ }^{1} \mathrm{Na}$ referida pesquisa, além de estudar a obra de Assia Djebar, também a levamos para a sala de aula e desenvolvemos uma pesquisa de Mestrado (em 2017), refletindo sobre a forma como o romance L'amour, la Fantasia (DJEBAR, 1985) se torna um caminho de resistência para as mulheres argelinas, mostrando como esta obra pode favorecer a quebra de estereótipos em sala de aula, além de otimizar o ensino/aprendizagem do Francês como Língua Estrangeira. Dissertação intitulada: L'amour, la Fantasia, de Assia Djebar: a literatura em aula de FLE como lugar de resistência feminina.
} 


\section{Reuista Leteas Paear}

ISSN: 2317-2347 - v. 7, Edição Especial (2018).

Djebar dá ênfase ao papel da mulher durante a guerra, narrando os feitos heroicos realizados por algumas de suas ancestrais durante a luta anticolonial.

Vemos que literatura se constitui como um espaço de subterfúgio para os escritores argelinos que enfrentaram o processo de despersonalização cultural e que, inseridos no contexto cultural de experiência híbrida, precisaram (re)criar uma nova identidade situada entre a cultura da antiga metrópole e a sua terra de origem, ou seja, no entrelugar franco-árabe. No tópico a seguir, refletiremos sobre a vida e obra da escritora argelina Assia Djebar, também situada neste entrelugar identitário.

\section{Assia Djebar: uma busca identitária alicerçada em dois mundos}

Se colocarmos em contraponto a crítica pós-colonialista e a corrente feminista, observamos a figura da mulher como metáfora da colonização: uma mulher da colônia é uma metáfora da mulher como colônia (BONNICI, 2009). Evidenciamos que a mulher argelina foi duplamente colonizada. Primeiramente, por integrar um povo que foi colonizado e, segundamente, pelo fato de ser marginalizada e tratada como inferior com relação ao homem. Desse modo, uma das mais eficazes estratégias de descolonização feminina consistiu na rota da linguagem e da experimentação linguística (ASHCROFT et al., 1991 apud BONNICI, 1998). A mulher do período pós emancipação política encontrou, na literatura, uma forma de lutar contra as marcas deixadas pela colonização até os dias de hoje.

Dentre as muitas escritoras magrebinas de língua francesa que expressaram em suas obras, as suas revoltas mediante o contexto de luta contra os vestígios da colonização e da afirmação de identidades culturais próprias, situadas no âmbito da literatura pós-colonial, citamos Malika Mokedden, médica por formação que, em 1985, deixou a medicina para se dedicar à literatura; também destacamos Leïla Sebbar cuja obra se debruça sobre as questões do universo da mulher, em denúncia, reflexões e exercício constante sobre a sua posição no mundo argelino e Salima Ghezali, que também compartilha desses mesmos ideais. Além de Ghezali, Hélé Béji, Maïssa Bey, Fatima Mernissi, Samira Negrouche, Hélène Cixous, Assia Djebar e muitas outras 


\section{Reuista Leteas Racas}

ISSN: 2317-2347 - v. 7, Edição Especial (2018).

escritoras fazem a voz da mulher magrebina ecoar para além das terras africanas (HOYET, 2013).

Aqui destacamos a escritora magrebina Fatima-Zohra Imalayène (1936-2015), conhecida como Assia Djebar (pseudônimo adotado) nascida em Cherchel, na Argélia, descendente de uma família da pequena burguesia tradicional argelina e filha de Tahar, professor de uma escola primária francesa no interior da Argélia e de Bahia Sahraoui, ambos árabes.

A vida de Djebar toma um rumo diferente do das demais mulheres da cultura árabe quando o seu pai a matricula em uma escola francesa aos cinco anos de idade (SOARES, 1990). Ela foi uma das raras mulheres que tiveram acesso à escolarização, passando sua infância na Argélia, indo morar em Paris, aos 18 anos, após a obtenção de uma bolsa de estudos (Lycée Fénelon). No ano seguinte, entra para a École Normale Supérieure de jeunes filles de Sèvres, na França, onde escolhe fazer o curso de História. Em 1956, decide seguir a greve da União Geral dos Estudantes Muçulmanos Argelinos e então é expulsa da escola de Sèvres. Nesta ocasião, escreve o seu primeiro romance: La soïf (1957), se casa com o escritor Walid Carn e deixa a França, partindo para o Norte da África.

Em 1959 Assia Djebar passa a ensinar História moderna e contemporânea do Magrebe na Faculdade de Letras do Rabat, no Marrocos. Em 1962 retorna à Argélia e passa a ensinar História na Universidade de Alger, até 1965, quando o ensino de História tornou-se obrigatório em língua Árabe. Então, de 1966 até 1975, passa a residir em Paris e fica entre idas e vindas para a Argélia.

Djebar se divorcia do seu primeiro marido e casa-se outra vez com Malek Alloula. Em 1999, defende a sua tese na universidade Paul-Valéry Montpellier e, no mesmo ano, é eleita membro da Academia Real de Língua e Literatura Francesas da Bélgica e em 2005, foi eleita membro da Academia Francesa. A partir de 2001, tornouse professora do departamento de estudos franceses da Universidade de Nova Iorque, tendo sido, de 1995 a 2001, diretora do Centro de estudos franceses e francófonos da Luisiana, nos EUA.

Após a sua primeira narrativa publicada, escreveu ainda várias outras obras, a saber: Les impatients (1958), Les Enfants du Nouveau Monde (1962), Les alouettes naïves (1967), Poèmes pour l'Algérie heureuse (1969), Rouge l'aube (1969), Femmes 


\section{Revista Leteas Racar}

ISSN: 2317-2347 - v. 7, Edição Especial (2018).

d'Alger dans leur appartement (1980), L'Amour, la Fantasia (1985), Ombre sultane (1987), Loin de Médine (1991), Vaste est la prison (1995), Le Blanc de l'Algérie (1996), Oran, langue morte (1997), Les Nuits de Strasbourg (1997), Ces voix qui m'assiègent: En marge de ma francophonie (1999), La Femme sans sépulture (2002), La Disparition de la langue française (2003), Nulle part dans la maison de mon père (2007). Assia Djebar dirigiu dois filmes intitulados La Nouba des femmes du Mont Chenoua (1978) e La Zerda ou les chants de l'oubli (1982), estruturados sob a forma de documentários que registraram testemunhos de mulheres que presenciaram diversas lutas travadas pela mulher argelina, tanto no âmbito da luta pela libertação do colonialismo francês, quanto no âmbito da resistência e da luta contra a subalternização imposta às mulheres argelinas.

No período pós-guerra, quando lecionou História na universidade de Argel, Djebar viu-se diante de um dilema: sendo uma historiadora árabe e conhecendo toda a opressão vivida pelo povo argelino, a sua língua de escrita era a mesma do colonizador. Desse modo, ela optou por afastar-se da literatura por mais de 10 anos, recorrendo, assim, ao cinema como um modo de voltar a entrar em contato com a língua árabe dialetal, que era a variante da sua língua materna. $\mathrm{O}$ cinema funcionou como um mediador entre a escritora e a sua própria cultura, uma vez que ela sentia que estava devendo algo à cultura do seu povo, por ser uma escritora de língua francesa e não de língua árabe. A sua angústia estava sempre neste entrelugar franco-árabe: apesar de ter vivido muito tempo na França e ter assimilado a cultura francesa, as suas raízes culturais eram árabes. Assim, vemos uma tentativa de reconciliação de Djebar com a sua identidade árabe, pelo meio cinematográfico (SOARES, 1990).

Tanto em sua expressão literária quanto em sua produção cinematográfica, Assia Djebar abordou questões em torno do universo feminino de maneira minuciosa, desde os aspectos físicos até os mentais, os sociais, os linguísticos etc., a partir de suas experiências íntimas e das suas reflexões pessoais. O principal tema encontrado em sua obra é a questão da emancipação da mulher durante a guerra da independência (19541962).

Vemos Assia Djebar, como uma escritora argelina que, desde criança, teve a sua vida marcada por uma dicotomia cultural que dividia a sua identidade em duas partes. 


\section{Reuista Leteas Racar}

ISSN: 2317-2347 - v. 7, Edição Especial (2018).

Essa cisão identitária manifestou-se em toda a sua obra e a levou a viver entre os universos francês e árabe.

\subsection{O entrelugar em quatro obras de Assia Djebar}

O primeiro romance que escreveu, La soïf (DJEBAR, 1957), foi publicado à época em que a Argélia ainda era um país-colônia. Também nesse período, Djebar havia retornado do exílio na França para o Marrocos. Nesse romance considerado por Orlando (2015) como um romance experimental influenciado pelo estilo e formas literárias do Nouveau roman ${ }^{2}$, é abordada uma contradição que aflige Nadia, uma jovem burguesa afrancesada, que é retratada como narcisista pelo fato de relacionar-se livremente com os outros, caminhar sozinha pela cidade, usar calças etc. transgredindo, assim, os limites culturais impostos às mulheres argelinas. Ela age como um corpo sem órgãos (DELEUZE; GUATARI, 2000), sendo impulsionada pelos seus desejos e subjetivações, sem deixar-se limitar pelas imposições sociais.

O enredo segue as ações de Nadia, que parece estar sempre preocupada com a sua imagem e em chamar a atenção dos homens que conhece. Em determinado momento, ela decide seduzir Ali, o marido da sua amiga, Jedla, que se sente culpada por achar que não pode ter filhos. Jedla incentiva a relação entre Nadia e Ali, para que ele tenha um pretexto para pedir o divórcio. Contudo, Jedla engravida. Mas, suas dúvidas sobre a fidelidade de Ali a levam a abortar; durante a operação, ela morre.

Ao caminhar às margens da sociedade argelina e, assim, entregar-se às suas paixões, Nadia prova do sentimento de liberdade. Contudo, no desfecho do romance, a personagem tem um sobressalto que a leva a perceber que a sua realidade individual é, na verdade, uma falsa liberdade. Ao olhar para os limites culturais que a aprisionam, Nadia se vê confrontada com os diversos julgamentos da Argélia dos anos de 1950 e, portanto, percebe que está, na verdade, muito longe do que busca, sentindo-se aprisionada e sem pátria. Neste momento, Nadia decide abandonar Ali e casa-se com

\footnotetext{
${ }^{2}$ Noveau Roman refere-se a um movimento literário francês dos anos 1950 que diverge dos gêneros literários clássicos. Alain Robbe-Grillet, foi o seu principal representante, tendo publicado uma série de ensaios sobre a natureza do novo romance que foram posteriormente reunidos na obra Pour un nouveau roman, em 1963 (ORLANDO, 2015).
} 


\section{Revista Leteas Racar}

ISSN: 2317-2347 - v. 7, Edição Especial (2018).

Hassein, com o intuito de negar as suas paixões e de reconciliar-se com as exigências da sociedade argelina.

Ao publicar este romance, Djebar constrói uma personagem cuja identidade está fragmentada e que busca criar situações que a levem a fugir da realidade social na qual está inserida, descrevendo a Argélia como um ambiente pacífico e com uma convivência harmoniosa entre os cidadãos. Quando, na verdade, a época em que o romance foi escrito foi uma das mais violentas da guerra pela independência da Argélia. É possível perceber a forma como a autora se sentia mediante a situação conflituosa do seu país de origem, buscando superar a existência do conflito e ultrapassá-lo, através da escrita.

Observamos nesse romance, a criação de um novo ambiente sociocultural, com diferentes condições sociopolíticas e culturais. Ao transgredir normas pré-estabelecidas às mulheres da época, a personagem Nadia vivencia um devir revolucionário (DELEUZE; GUATARI, 2000), subjetivando-se, vivendo a liberdade da qual estava sedenta e, também, buscando a superação da dolorosa história da colonização vivenciada pelo seu país, a partir da criação de um jornal bilíngue: francês e árabe, no qual se fale sobre outras coisas além da colonização, como se pode verificar no excerto abaixo:

- (...) Sim, nossa imprensa está podre. Mas isso não me desencoraja; há muito a se fazer em nosso país. Estou contente por estar de volta à Alger; o jornal que vou montar será bilingue: francês e árabe. Será difícil, eu não me iludo. Mas se no início eu conquistar os jovens, poderei conseguir. (...). O pior é a letargia, o sono! Não se fala em mais nada além dos colonos, do colonialismo. O mal, veja, é a nossa mentalidade de colonizados, de colonizáveis. É isso que é preciso socorrer, é isso é que é preciso dizer em nossa língua. (DJEBAR, 1957, p. 44. Tradução nossa. Grifo nosso. $)^{3}$.

Quando a personagem Nadia menciona que é preciso dizer que o mal seria a mentalidade de colonizados em árabe (e também em francês), observa-se claramente a forma como essa personagem busca a ultrapassagem do colonialismo e o desejo de que

\footnotetext{
3 “- (...) Oui, disait-il, notre presse est pourrie. Mais cela ne me décourage pas ; il y a énormément à faire dans notre pays. Je suis content de revenir à Alger; le journal que je vais monter sera bilingue : français et arabe. Ce sera difficile, je ne me fais pas d'illusion. Mais si seulement au début je gagne à moi tous les jeunes, je pourrai tenir. (...) Le pire, c'est la léthargie, le sommeil ! On ne parle toujours que des colons, du colonialisme. Le mal, voyez-vous, c'est notre mentalité de colonisés, de colonisables. C'est cela qu'il faut secouer, c'est ce qu'il faut leur dire dans notre langue.” (DJEBAR, 1957, p. 44.)
} 


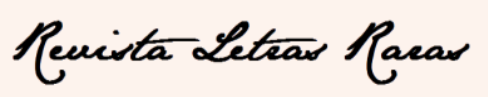

ISSN: 2317-2347 - v. 7, Edição Especial (2018).

uma nova geração faça algo pelo seu país, retirando-o da subordinação de colônia; e é isso o que a jovem escritora busca fazer ao escrever tal romance: revolucionar a Argélia à época da Guerra pela libertação nacional. Aqui o devir revolucionário se concretiza (DELEUZE; GUATARI, 2000): no interstício de uma guerra e de uma libertação nacional.

Ao escrever tal romance na época do regime colonial, Djebar rompeu com as proibições morais impostas à mulher argelina. Situada no entrelugar franco-árabe, estando com a sua identidade cultural fragmentada após tanto tempo morando na França, ela expressa, através do romance $L a$ soïf, a sede de independência, de liberdade e de mudança que deseja para o seu país.

Em L'amour la Fantasia (DJEBAR, 1985), primeiro romance que figura o projeto autobiográfico traçado por Djebar, a autora situa a mulher como metáfora da Argélia colonizada. Nesse romance a narrativa foca ações heroicas de mulheres argelinas durante a luta anticolonial, trazendo relatos de como essas mulheres lutaram e resistiram aos massacres ocorridos em terras argelinas. Através da sua "escrita-ferida" (REGAIEG, 1999, p. 2), Djebar intercala capítulos dedicados à história da luta anticolonial argelina e capítulos dedicados à sua própria história. Nesse romance, observa-se que se delineia uma espécie de agenciamento molecular (DELEUZE; GUATARI, 2000), no qual a escrita literária funciona como uma linha de fuga para a expressão das subjetividades e desejos das personagens mulheres, as quais vivem um devir revolucionário, lutando pela sua nação e pelos ideais nos quais acreditavam.

Percebemos a forma como a guerra social em sua terra natal provocou na autora um conflito identitário. Alguns capítulos do referido romance revelam uma narradora que escreve para compreender a si mesma e para compreender a sua história. E esta compreensão só se dá, no momento em que ela revisita o passado do seu país e o passado das mulheres argelinas cujas histórias são narradas no decorrer do romance. O conflito identitário vivido por Djebar e narrado em L'amour, la Fantasia (1985) é revelado quando são evocados episódios da vida pessoal da autora, que apontam a contradição linguística e cultural como fatores ambivalentes e problemáticos.

No primeiro capítulo, a figura de Tahar, o pai de uma menina (ambos argelinos), desde o princípio do romance sinaliza o problema da dupla pertença territorial e cultural com relação à Europa e à África. Sendo Tahar professor de uma escola colonial francesa 


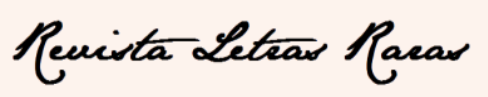

ISSN: 2317-2347 - v. 7, Edição Especial (2018).

ele conduz a sua filha a essa escola; as suas vestes e a sua língua de uso eram europeias, mas a sua origem cultural, não. Assim é permeada a vida da personagem narradora do romance, muito semelhante ao dilema expresso por Assia Djebar em suas demais obras: percursos marcados pela ambivalência cultural e por esta situação de interstício, de entrelugar (BHABHA, 2005): uma escritora francófona, que se encontra como esta menina, em meio a dois territórios e a duas línguas.

Ces voix qui m'assiègent (DJEBAR, 1999) consiste em uma compilação de textos poéticos, de narrativas curtas e de autoanálises, na qual Assia Djebar procura afirmar a sua identidade enquanto escritora franco-árabe através de apreciações a respeito de algumas de suas próprias obras escritas até então. A personagem principal, Fátima-Zohra, se coloca como uma leitora dos textos da escritora francófona Assia Djebar e assim, a sua recepção aos textos da mencionada escritora é refletida e desenvolvida, por meio das vozes de várias mulheres que, ora falam em francês, ora falam em árabe, ora falam em berbere.

Assim, esta obra que concentra uma reflexão identitária sobre Djebar enquanto escritora francófona que utiliza a língua francesa (língua imposta e não escolhida) para falar sobre as suas origens e para dar voz às mulheres ancestrais que não tiveram espaço para falar e para escreverem as suas próprias histórias. $\mathrm{O}$ desconforto provocado pelo entrelugar franco-árabe leva Assia Djebar a analisar-se através da sua própria obra, pois é assim que ela conseguia (re)construir-se: através da escrita literária.

Em Nulle part dans la maison de mon père (DJEBAR, 2007), último romance escrito por Assia Djebar, encontramos uma personagem narradora chamada FatimaZohra (mesmo nome civil de Assia Djebar) que põe em cena as suas lembranças pessoais de infância e de adolescência. Nesta trilha literária por uma busca identitária, ela narra a história de Fatima, cujo pai intelectual e autoritário inicia a sua filha no 'mundo' do colonizador. Assim, alguns hábitos do cotidiano reforçam o entrelugar franco-árabe dentro da casa da menina: o pai que lê jornais escritos em língua francesa e a mãe que ouve, diariamente, emissões de rádio em árabe.

Em uma entrevista concedida ao Jornal Jeune Afrique, Djebar explica que escreveu Nulle part dans la maison de mon père (DJEBAR, 2007) para narrar um grave momento de turbulência em sua adolescência que a levou a tentar suicídio após ter sido humilhada pelo seu noivo, em 1953. Esclarece que esse romance é, para ela, uma 


\section{Revista Leteas Racar}

ISSN: 2317-2347 - v. 7, Edição Especial (2018).

espécie de autoanálise, no qual ela reúne elementos da sua infância e adolescência para compreender a si mesma (BARRADA, 2008). Assim, os conflitos desenvolvidos no romance em questão refletem indagações e buscas pessoais da autora, revelando que é através da literatura que Assia Djebar busca compreender o entrelugar franco-árabe no qual sempre esteve situada.

\section{Conclusão}

Desde a sua entrada para a Academia Francesa, em 2005, a produção literária de Assia Djebar tornou-se uma das mais estudadas nas universidades americanas. Não apenas nessa região, mas, também na França e em diversos outros países, inclusive no Brasil, as suas obras literárias chamaram atenção dos estudiosos e críticos literários. Ao desenvolver um projeto autobiográfico que se articula estreitamente com narrativas que contam a história da sua nação, as histórias individuais narradas por Djebar evocam a história de mulheres argelinas, denunciando a subalternização imposta a essas mulheres.

Portanto, o seu trabalho minucioso de narrações múltiplas que narram a si mesma e à sua nação, veiculado em língua francesa tem, desde as suas primeiras publicações, provocado muitos estudiosos a desenvolverem reflexões a respeito da sua escrita. Em âmbito internacional, vários trabalhos, a saber: teses, dissertações, ensaios, artigos publicados em revistas, dentre outros gêneros, têm sido realizados, no intento de explorar a escrita de Assia Djebar.

A maior parte desses estudos desenvolvidos exploram o caráter autobiográfico das suas obras, bem como a pluralidade de vozes que narram os seus romances, como é feito em Najiba (1995), Chih (2004), Hacib (2010), Benalil (2004), Regaieg (1999) e em muitos outros trabalhos. Alguns outros estudos buscam realizar comparações entre as suas obras e a de outros escritores magrebinos, como é feito em Lameirinha (2013), que compara La disparition de la langue française (DJEBAR, 2003) com Le premier homme (1994), de Albert Camus.

Porém, pouco se tem discutido a respeito do entrelugar franco-árabe no qual a escritora esteve situada desde a infância. Há trabalhos que mencionam este conflito identitário de Djebar, mas, ainda não há estudos que analisem este entrelugar manifesto em sua obra literária. Ademais, no Brasil essa autora ainda é pouco conhecia e estudada. 


\section{Reuista Letear Racar}

ISSN: 2317-2347 - v. 7, Edição Especial (2018).

Em seus romances, é perceptível a hibridez cultural de que fala Homi Bhabha (2005) e, também, os devires revolucionário e mulher situados por Deleuze e Guatari (2000), nas personagens femininas.

Assim, ao longo deste artigo buscamos discutir elementos que reafirmam o entrelugar literário na obra da referida escritora, bem como situá-la como uma autora que sofreu os impactos do regime colonialista instalado em seu país e, dentre tantas outras consequências nefastas, a ruptura identitária alcançou a subjetividade de Djebar e fragmentou a sua identidade em duas partes, situando-a no entrelugar franco-árabe e causando diversas marcas de fragmentação expressas em suas obras, manifestas pelos sentimentos de afasias de afeto, melancolia e busca de compreensão de si mesma e das culturas que lhe perpassam e que lhe constituem. O entrelugar literário no qual Djebar se situa provoca em sua escrita a evocação da sua cultura de origem e alguns questionamentos permitidos pela liberdade que a cultura francesa lhe concedeu.

\section{REFERÊNCIAS}

AMROUCHE, M. T. La rue des tambourins. Paris, Table Ronde, 1960.

ASHCROFT, B. et al. The empire writes back: theory and practice in post-colonial literatures. Londres: Routledge, 1989.

ALMEIDA, I. B. S. Culturas africanas, culturas diaspóricas: uma reflexão. Revista Histórias e perspectivas. Uberlândia. 197.214, jul. dez. 2010.

BARRADA, H. T. C. «Assia Djebar» Journal Jeune Afrique, 2008. Disponível em: http://www.jeuneafrique.com/57084/archives-thematique/assia-djebar/ Acesso em: 26 de setembro de 2017.

BENALIL, M. L'autobiographie et les enjeux du dialogisme culturel dans 'L'amour, la Fantasia' d'Assia Djebar. Rencontre des cultures et enjeux identitaires, Revista Diálogos, 2004.

BHABHA, H. K. O local da cultura. Belo Horizonte: Editora UFMG, 2005.

BOAHEN, A. A. História geral da África, VII: África sob dominação colonial, 18801935 - 2.ed. rev. - Brasília: UNESCO, 2010.

BONNICI, T. Teoria e crítica pós-colonialistas. In: Teoria literária: abordagens históricas e tendências contemporâneas. Maringá: Eduem, 2009: 257-286.

CHIH, Z. L'Amour, la fantasia d'Assia Djebar: de l'écriture autobiographique à l'écriture des cris. Synergies. Algérie n 21 - 2014 p. 29-43.

COMBE, D. Les littératures francophones - questions, débats, polémiques. Presses Universitaires de France. Paris, 2010. 


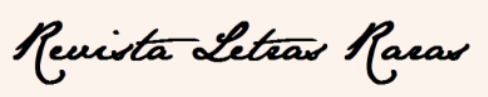

ISSN: 2317-2347 - v. 7, Edição Especial (2018).

DELEUZE, G; GUATARI, F. Como criar para si um corpo sem órgãos. Mil platôs. Capitalismo e esquizofrenia. Vol. 3. São Paulo: Editora 34, 2000.

DIB, M. L'Incendie. Paris, Le Seuil, 1954.

DJEBAR, A. La Soif. Paris: Julliard, 1957.

. L'amour, la Fantasia. Paris : Albin Michel, 1985.

. Ces voix qui m'assiègent... en marge de ma francophonie. Paris : Albin Michel, 1999.

. Nulle part dans la maison de mon père. Paris: Fayard, 2007.

GIL, A. C. Métodos e técnicas de pesquisa social. São Paulo: Editora Atlas, 2008.

GLISSANT, É. Introduction à une Poétique du Divers. Montréal: PUM, 1995.

HOYET M.-J. Leila Sebbar, Malika Mokeddem, Maïssa Bey, Fatima Mernissi, Hélé Beji. Magazine Babelmed - cultures méditerranéennes en ligne. Roma, 2013.

KATEB, Y. Nedjma. Paris, Le Seuil, 1956.

LAMEIRINHA, C. A. B. Língua, exílio e memória: uma leitura comparativa de $L e$ Premier Homme, de Albert Camus e La disparition de la langue française, de Assia Djebar. Tese apresentada ao Programa de Pós-Graduação em Estudos Linguísticos, Literários e Tradutológicos em Francês. USP - São Paulo, 2013.

LUKÁCS, G. A teoria do romance; Um ensaio histórico filosófico sobre as formas da grande épica. Trad., posfácio e notas José Marcos Mariani de Macedo. São Paulo: Duas Cidades/Editora 34, 2000. p. 7-19.

MEMMI, A. Portrait du colonisé, précédé du portrait du colonisateur. Paris, Payot, 1957.

MINTZ, S.; PRICE, R. O Nascimento da cultura Afro-Americana. Uma perspectiva antropológica. Rio de Janeiro: Editoria Pallas e Centro de estudos Afro-Asiáticos, 2003.

NAJIBA, R. L'autobiographie à la fiction ou le je(u) de l'écriture : étude de L'Amour, la Fantasia et d'Ombre sultane d'Assia Djebar. 1995. 395 f. Thèse de doctorat de littérature française - Université Paris Nord, U.F.R. Lettres, Departement de Français. 1995.

NETO, M. L. A. A sociologia da literatura: origens e questionamentos. Revista Entrelaces: Ceará, 2007.

ORLANDO, V. La Soïf d'Assia Djebar: pour un nouveau roman maghrébin. Revista El-Khitab. Université de Maryland, USA, 2015. Disponível em: http://revue.ummto.dz/index.php/khitab/article/viewFile/1226/1027. Acesso em: 22 de setembro de 2017.

PEREIRA, K. R. W.; SOUZA, F. Z. D. Diáspora, exílio e memória nas literaturas africanas em Língua Portuguesa. Assis: Revista Miscelânea, 2016.

RAMALHO, Y. A. O exílio no romance 'Primavera con una esquina rota de Mario Benedetti'. 2013. 72 p. Dissertação de mestrado - Universidade Federal do Rio Grande do Norte, Programa de Pós-graduação em estudos da linguagem. 


\section{Reuista Letras Racar}

ISSN: 2317-2347 - v. 7, Edição Especial (2018).

REGAIEG, N. L'amour, la Fantasia d'Assia Djebar: de l'autobiographie à la fiction. Extrait de la revue Itinéraires et contacts de cultures, Paris, L'Harmattan et Université Paris $13, \mathrm{n}^{\circ} 27,1^{\circ}$ semestre 1999.

SILVA, M. R. S. 'L'amour, la Fantasia', de Assia Djebar: a literatura em aula de FLE como lugar de resistência feminina. 2017. 200 f. Dissertação (Mestrado em Linguagem e Ensino) - Universidade Federal de Campina Grande - UFCG. Campina Grande. 2017.

SOARES, V. L. A situação linguística e a literatura de expressão francesa no Maghreb. Revista Fragmentos, Florianópolis: UFSC, 1990.

UZOIGWE, G. N. Periodização do colonialismo na África. In: História geral da África VII- África sob dominação colonial, 1880-1935 - 2.ed. rev. - Brasília: UNESCO, 2010. 